\title{
PENGARUH MOTIVASI WISATA, PERSEPSI TENTANG DAYA TARIK DAN KUALITAS PELAYANAN TERHADAP LAMA TINGGAL WISATAWAN DI PROVINSI DIY
}

\author{
Nur Budhi Puji Wibowo \\ Program Studi Magister Kajian Pariwisata \\ Sekolah Pasca Sarjana Universitas Gadjah Mada
}

\begin{abstract}
The aim of this research is to find out and analyze the influence of tourist motivation and perception of the destination attractiveness and tourism service quality to the tourist's length of stay in Yogyakarta Special Province. As one of the most outstanding tourism destination in Indonesia, this province is visited by over than one million domestic and foreign visitors every year. Visitor's length of stay as one of the important indicators of tourism development success plays significant role to maximize the economical benefits in order to increase prosperity for the local community. Therefore, this research means very important to understand the influence's significances of each independent variables both in single and aggregate to the tourist's length of stay in Yogyakarta Special Province.

The research result shows that variable of tourist motivation has a positive and significant influence for the domestic tourist's length of stay in Yogyakarta Special Province. However, for the foreign tourists it has no significant influence for their length of stay. The variable of perception of the destination attractiveness has no significant influence for the domestic tourist's length of stay in Yogyakarta Special Province. In the other hand, it has a positive and significant influence for the foreign tourist's length of stay. Afterward, the variable of perception of the tourism service quality has no significant influence for the domestic tourist's length of stay in Yogyakarta Special Province. In the other side, it has a positive and significant influence for the foreign tourist's length of stay. In aggregate, the variable of tourist's motivation and perception of the destination attractiveness and tourism service quality have a positive and significant influence for the tourist's length of stay in Yogyakarta Special Province both for domestic and foreign tourist. The values of determination coefficients for each tourist group are $26,1 \%$ and $16,1 \%$.
\end{abstract}

\section{Keywords:}

tourist motivation, destination attractiveness, tourism service quality, length of stay.

\section{INTISARI}

Tujuan penelitian adalah untuk mengetahui dan menganalisis pengaruh motivasi wisatawan dan persepsi daya tarik dan kualitas layanan wisata terhadap lama tinggal wisatawan di Provinsi Daerah Istimewa Yogyakarta. Sebagai destinasi wisata kedua di Indonesia, provinsi DIY dikunjungi oleh lebih dari satu juta pengunjung dalam dan luar negeri setiap tahun. Lama tinggal wisatawan menjadi indikator penting dalam mengukur keberhasilan pembangunan pariwisata memainkan peran penting untuk memaksimalkan manfaat ekonomis dalam rangka meningkatkan kesejahteraan bagi masyarakat setempat. Oleh karena itu, penelitian ini sangat penting untuk memahami signifikansi pengaruh 
dari setiap variabel independen dengan lama tinggal wisatawan di Daerah Istimewa Yogyakarta.

Hasil penelitian menunjukkan bahwa variabel motivasi wisatawan memiliki pengaruh positif dan signifikan terhadap lama wisatawan domestik yang tinggal di Provinsi DIY. Namun, bagi para wisatawan asing tidak memiliki pengaruh signifikan untuk lama tinggal mereka. Variabel persepsi daya tarik tidak memiliki pengaruh signifikan terhadap lama tinggal wisatawan domestik. Pada sisi lain memiliki pengaruh positif dan signifikan terhadap lama tinggal wisatawan asing. Setelah itu, variabel persepsi kualitas jasa pariwisata tidak memiliki pengaruh signifikan terhadap lama tinggal wisatawan domestik. Secara keseluruhan, variabel motivasi wisatawan dan persepsi daya tarik destinasi dan kualitas jasa pariwisata memiliki pengaruh positif dan signifikan terhadap lama tinggal wisatawan di Provinsi DIY, baik untuk wisatawan domestik maupaun asing. Nilai koefisien determinasi untuk setiap kelompok wisatawan adalah $26,1 \%$ dan $16,1 \%$.

\section{Kata Kunci:}

wisata motivasi, daya tarik tujuan, pariwisata kualitas pelayanan, lama tinggal.

\section{PENDAHULUAN}

Pariwisata internasional menunjukan perkembangan yang terus meningkat. Menurut UNWTO pada tahun 2004 pariwisata internasional mencapai puncak tertinggi sepanjang sejarah dengan mencapai angka 763 juta orang, dan menghasilkan pengeluaran sebesar US\$ 623 miliar. Diperkirakan jumlah perjalanan pariwisata di dunia pada tahun 2010 akan menembus angka 1 miliar orang, dan di tahun 2020 akan melampaui 1,5 miliar orang per tahun.

Indonesia sebagai salah satu negara di kawasan Asia Tenggara yang mengalami pertumbuhan paling tinggi mencatat pertumbuhan kunjungan wisata sebesar 19,1\% atau 5,321 juta orang dengan total pendapatan devisa sebesar US\$. 4,798 miliar pada tahun 2004. Namun demikian, dalam peta persaingan pariwisata di kawasan Asia Tenggara, kondisi kepariwisataan nasional kita jika diukur dari jumlah kunjungan wisatawan dan tingkat penerimaan devisa negara yang dihasilkan masih berada di urutan nomor 4 dibawah Malaysia, Thailand, dan Singapura (UNWTO, unwto.org).

Tujuan penelitian adalah untuk mengetahui berbagai hal yang berkaitan dengan lama tinggal wisatawan, dilihat dari berbagai faktor yang mempengaruhinya. Secara rinci tujuan yang ingin dicapai adalah untuk mengetahui dan menganalisis pengaruh motivasi wisata, persepsi wisatawan tentang daya tarik destinasi dan kualitas pelayanan wisata di Provinsi DIY baik secara sendiri maupun bersama sama terhadap lama tinggal.

Penelitian dilaksanakan di Provinsi DIY. Seluruh proses penelitan dilaksanakan dalam waktu 7 bulan yaitu dimulai pada bulan Agustus 2009 s/d Februari 2010. Berdasarkan metode, bentuk penelitian adalah penelitian survey. Populasinya adalah wisatawan yang berkunjung ke Provinsi DIY pada saat penelitian dilakukan. Sampel ditentukan dengan teknik Random Sampling. Jumlah sampel yang diambil adalah sebanyak 100 orang untuk masing-masing jenis wisatawan (wisatawan domestik dan wisatawan asing), sehingga totalnya adalah 200 orang. Untuk menganalisis data penelitian, digunakan an॰lisis statistik yaitu teknik korelasi dan regresi baik secara tunggal maupun berganda dengan menggunakan bantuan software SPSS 17.0 Series. Selain itu juga digunakan teknik tabel silang terhadap beberapa variabel penelitian yang dianggap penting.

\section{KONDISI AKTUAL KEPARIWISATAAN DIY}

Provinsi DIY dikenal sebagai salah satu destinasi dengan kekayaan budaya dan 
warisan budaya yang melimpah. Candi Prambanan, Kraton Kasultanan Yogyakarta, Kawasan Kotagede dan bangunan-bangunan eks Belanda (bangunan indies) merupakan salah satu bukti kebesaran masa lalu yang masih eksis. Jarak yang relatif dekat dan mudah dijangkau dengan kawasan heritage lain (diluar batas administrasi Provinsi DIY) seperti Candi Borobudur, Kasunanan Surakarta, Dieng, Klentheng- klentheng tua di Semarang dan beberapa obyek wisata lain menjadikan Provinsi DIY memiliki nilai tambah tersendiri.

Untuk mendukung perkembangan sektor pariwisata, di Provinsi DIY telah tersedia berbagai sarana pendukung yang dapat dimanfaatkan oleh wisatawan meliputi fasilitas akomodasi mulai dari hotel bintang 5 sampai dengan hotel kelas melati, restoran, agen perjalanan wisata yang cukup memadai.

Dari sisi accessibilities, Provinsi DIY didukung dengan telah tersedianya berbagai moda transportasi utamanya transportasi darat dan udara. Provinsi DIY memiliki Bandara Internasional Adisutjipto, yang setiap minggunya melayani penerbangan ke lebih dari 40 destinasi, baik dalam negeri maupun luar negeri. Selain itu juga terdapat stasiun kereta api Tugu, melayani perjalanan kereta api ke berbagai kota tujuan di Pulau Jawa, serta Terminal Bis Giwangan yang juga melayani perjalanan ke berbagai kota tujuan baik di Pulau Jawa, Sumatera, dan Bali.

Ketersediaan sarana transportasi lokal juga semakin membaik. Hal ini terutama setelah beroperasinya bus Trans Jogja yang menghubungkan berbagai wilayah di Provinsi DIY, utamanya daerah-daerah jalur wisata. Selain itu berbagai moda transportasi seperti Taksi, Bis Kota, persewaan mobil, hingga alat transportasi tradisional semacam becak dan andong wisata juga tersedia cukup.

Wisatawan yang bekunjung ke Provinsi DIY secara garis besar terbagi menjadi 2 kelompok yaitu wisatawan asing dan wisatawan nusantara. Untuk wisatawan asing, terdapat sepuluh besar wisatawan asing yang menjadi pasar utama. Belanda, Jepang,
Jerman, dan Perancis merupakan pemasok utama wisatawan ke Provinsi DIY. Namun demikian, pada tahun 2008, jumlah wisatawan dari Malaysia mengalami peningkatan yang sangat signifikan. Hal ini sangat dimungkinkan karena pada tahun 2008, telah dibuka penerbangan langsung dari negara tersebut ke Yogyakarta oleh maskapai Air Asia dan Malaysia Airlines.

Untuk wisatawan domestik, pada tahun 2008 provinsi DIY dikunjungi oleh wisatawan yang berasal dari seluruh provinsi di Indonesia. Pemasok utama wisatawan domestik adalah berasal dari Provinsi DKI Jakarta, kemudian disusul oleh Jawa Barat, Jawa Tengah, Jawa Timur, dan Bali. Kelima provinsi tersebut memberikan andil terhadap lebih dari 50\% jumlah wisatawan domestik yang berkunjung ke Provinsi DIY. Namun demikian rata-rata lama tinggal wisatawan baik domestik maupun asing di Provinsi DIY ini masih tergolong rendah yaitu kurang dari 2 hari.

\section{PROFILE RESPONDEN}

\section{Wisatawan Domestik}

Penelitian ini berhasil menjaring responden yang berasal dari 16 provinsi di Indonesia. Sebagian besar berasal dari Provinsi Jawa Barat, Jawa Timur, Jawa Tengah, Banten, dan DKI Jakarta. Mayoritas berjenis kelamin laki-laki (62\%) dan sisanya perempuan. $47 \%$ responden berusia muda yaitu berkisar antara 24-30 tahun, disusul oleh responden dengan kelompok usia antara 31 s/d 37 tahun sebesar $22 \%$. Sebagian besar mereka berprofesi sebagai pegawai swasta $(42 \%)$, kemudian yang berprofesi sebagai mahasiswa sebesar $16 \%$. Mayoritas berpendidikan setingkat akademi/universitas (67\%).

Motivasi wisata sebagian besar responden adalah fisiologis yaitu sebesar $44 \%$. Mereka berwisata untuk menikmati wisata kuliner, berbelanja, wisata kesehatan, kecantikan dan olahraga. Kelompok terbesar kedua adalah wisatawan yang didorong oleh motif penghargaan yaitu sebesar $26 \%$. 
Mereka datang dengan maksud utama untuk mempelajari kebudayaan, sejarah, pendidikan, mengikuti kursus, seminar, pelatihan, meeting, pameran, dan sejenisnya. $(68 \%)$ responden mengatur sendiri perjalanan wisatanya.

Dari segi akomodasi yang diperguna kan, mereka memiliki proporsi yang hampir berimbang antara hotel berbintang, hotel non bintang, dan mereka yang menginap di rumah keluarga, kerabat atau teman. Lama tinggal selama 2 hari (45\%), dan yang tinggal selama 3 hari sebesar $25 \%$. Dilihat dari tingkat pendapatan per bulan, mayoritas berpenghasilan Rp2.000.001 s/d Rp.3.000.000. Adapun tingkat pengeluaran wisata mayoritas responden antara Rp250.000 s/d Rp500.000 per hari. Kebayakan dari mereka diketahui telah melakukan kunjungan sebanyak 2 kali yaitu sebesar $34 \%$, kemudian yang baru kali ini mengunjungi Provinsi DIY sebanyak 33\%.

Sebanyak $94 \%$ responden mengunjungi Kawasan Malioboro, kemudian 61\% dari mengunjungi Candi Prambanan, dan 59\% mengunjungi Keraton Yogyakarta. Hal ini dapat dipahami karena ketiga obyek wisata tersebut diatas merupakan ikon utama kepariwisataan Provinsi DIY. Mayoritas wilayah aktivitas wisata mereka berada di Kota Yogyakarta yaitu sebesar 50\%. Kemudian 20\% berada di Kabupaten Sleman dan $16 \%$ di Kabupaten Bantul.

\section{Wisatawan Asing}

Survey yang dilakukan berhasil menjaring responden yang berasal dari 23 negara. Mereka sebagian besar berasal dari negaranegara Eropa Barat dan wisatawan asal Belanda yang paling banyak yaitu sebanyak $13 \%$. Negara kedua terbanyak adalah Jerman dengan $12 \%$. Mayoritas mereka berjenis kelamin laki-laki yaitu sebesar $55 \%$, dan sisanya perempuan. Sebanyak $35 \%$ responden berusia 21-28 tahun,kemudian yang berusia antara 29-36 tahun yaitu sebesar 32\%. Mereka kebanyakan berprofesi sebagai pekerja profesional di berbagai bidang. Seperti: sales, marketer, doctor, hotelier, specialist, manager, technician, electrician, dan sebagainya.

Sebanyak $45 \%$ responden berwisata karena didorong oleh motif fisiologis. Motivasi utama mereka adalah untuk menikmati keindahan alam dan budaya, bersantai/ menghilangkan kejenuhan, wisata kuliner, berbelanja, wisata kesehatan, kecantikan, dan olahraga. Kelompok terbesar kedua adalah responden yang didorong oleh motif penghargaan diri yaitu sebesar 29\%. Mereka datang dengan maksud utama untuk mempelajari kebudayaan, sejarah, melanjutkan pendidikan, mengikuti kursus, training, seminar, pelatihan, mengikuti meeting, pameran, dan sejenisnya.

Mayoritas responden (74\%) mengatur sendiri perjalanan wisatanya. Hanya $23 \%$ dari responden mempercayakan perjalanan diatur oleh travel agent. Mereka umumnya memilih tinggal di hotel berbintang 58\%. Responden memilih hal itu karena menginginkan jaminan kenyamanan, keamanan dan kualitas pelayanan yang baik. Selain itu, 35\% responden memilih hotel non bintang sebagai tempatnya menginap. Umumnya mereka tinggal di hotel yang berada di kawasan Malioboro dan Prawirotaman.

Dari hasil survey diketahui bahwa $43 \%$ wisatawan mengunjungi Jakarta terlebih dahulu. Masuk ke Indonesia melalui Bandara Internasional Soekarno Hatta. Prosentase terbesar kedua (16\%) adalah responden yang langsung masuk ke Provinsi DIY melalui Bandara Internasional Adisutjipto. Mereka memanfaatkan penerbangan langsung JogjaKualalumpur.Selanjutnya kelompok terbesar ketiga (15\%) adalah responden yang masuk ke Provinsi DIY melalui Bali.

Mayoritas responden (74\%) akan mengunjungi Bali. Ini menunjukkan bahwa Bali merupakan destinasi utama mereka. Lama tinggal di destinasi setelah Provinsi DIY cukup bervariasi. $41 \%$ responden berencana tinggal selama 7 hari atau lebih di destinasi berikutnya. Kemungkinan besar destinasi itu adalah Bali karena mayoritas kunjungan mereka setelah Provinsi DIY adalah Bali.

Proporsi terbanyak lama tinggal 
responden wisatawan asing adalah 2 hari. Hal ini dimungkinkan karena mereka hanya mengunjungi obyek-obyek wisata utama saja seperti Candi Prambanan, Keraton, Malioboro dan Candi Borobudur di Magelang. Dari segi pendapatan, $46 \%$ responden berpendapatan lebih dari 1000 US\$ per bulan, kemudian disusul oleh responden dengan pendapatan antara 751 s/d 1000 US\$, per bulan (24\%). Responden yang menghabiskan uangnya < 50 US\$ per hari sebanyak 19\%, pengeluaran antara $51 \mathrm{~s} / \mathrm{d} 100$ US\$ sebesar $34 \%$, dan antara 101 s/d 150 US\$ sebesar 31\%.

Mayoritas responden $(85 \%)$ baru pertama kali mengunjungi Provinsi DIY. Secara garis besar mereka berkunjung ke 19 obyek wisata yang ada. Candi Prambanan dan Candi Borobudur merupakan tujuan utama mereka. Kedua candi tersebut dikunjungi oleh $96 \%$ responden. Selanjutnya Keraton Yogyakarta dan kawasan Malioboro masing-masing dikunjungi oleh $78 \%$ responden. Jika dilihat dari wilayah aktivitas wisatanya, diketahui bahwa $45 \%$ aktivitas wisata mereka berada di kawasan Kota Yogyakarta, 28\% di Kabupaten Sleman dan $20 \%$ di kawasan Candi Borobudur.

\section{PENGARUH MOTIVASI WISATA TERHADAP LAMA TINGGAL WISATAWAN}

\section{Wisatawan Domestik}

Hasil analisis menunjukkan bahwa terdapat pengaruh positif dan signifikan antara motivasi wisata terhadap lama tinggal wisatawan (LOS). Hal ini berarti bahwa motivasi wisata bagi wisatawan domestik merupakan faktor yang penting berkaitan dengan lama tinggalnya. Dengan kata lain, semakin tinggi motivasi wisatanya maka akan semakin tinggi pula lama tinggalnya.

Hal ini didukung oleh adanya fakta bahwa kelompok wisatawan yang datang ke Provinsi DIY untuk mengikuti berbagai acara atau event /wisata MICE (Meeting, Incentive, Conference, Exhibition) yang tercakup dalam kelompok motif penghargaan (self esteem), ternyata tinggal lebih lama dibandingkan dengan kelompok wisatawan yang datang dengan tujuan utama untuk berbelanja atau berwisata kuliner saja atau untuk mengunjungi saudara (motif fisiologis dan motif kasih sayang).

\section{Wisatawan Asing}

Hasil analisis menunjukkan bahwa tidak terdapat pengaruh yang signifikan antara motivasi wisata terhadap lama tinggal wisatawan (LOS). Oleh karena itu maka dapat disimpulkan bahwa ternyata motivasi wisata bagi wisatawan asing tidak berpengaruh signifikan terhadap lama tinggalnya. Hal ini disebabkan karena mayoritas wisatawan hanya menempatkan destinasi Provinsi DIY sebagai destinasi alternatif atau tambahan saja, bukan menjadi destinasi utama (main destination) dalam kunjungannya ke Indonesia.

Data penelitian ini juga menunjukkan bahwa mayoritas destinasi utama mereka adalah Bali. Hal ini dapat dipahami karena Bali sampai saat ini masih menjadi magnet utama bagi wisatawan asing yang berkunjung ke Indonesia. Adapun kunjungan mereka ke Provinsi DIY lebih disebabkan karena letaknya yang secara geografis berada dalam jalur wisata yang akan di lalui, atau karena faktor kekhasan daya tarik destinasi ini yang berbeda dengan destinasi utamanya. Selain itu bagi wisatawan yang menggunakan jasa travel agent, mereka harus berkunjung ke Provinsi DIY karena destinasi ini sudah tercakup dalam paket wisata yang telah di beli.

Temuan lain yang diperoleh adalah bahwa hanya sedikit wisatawan asing yang menjadikan Provinsi DIY sebagai tujuan wisata utamanya. Kemungkinan besar mereka adalah wisatawan dari Malaysia dan langsung pulang pasca berwisata di Provinsi DIY. Lebih lanjut, kelompok ini juga memiliki lama tinggal yang relatif singkat, dan biasanya kunjungan itu dilakukan pada akhir weekend saja selama 1 sampai 2 hari. 
PENGARUH PERSEPSI TENTANG DAYA TARIK DESTINASI TERHADAP LAMA TINGGAL WISATAWAN

\section{Wisatawan Domestik}

Tidak terdapat pengaruh yang signifikan antara persepsi tentang daya tarik destinasi terhadap lama tinggal wisatawan (LOS). Hal ini berarti bahwa persepsi wisatawan tentang daya tarik destinasi Provinsi DIY ternyata tidak cukup kuat untuk membuat mereka tinggal lebih lama lagi. Dengan kata lain, seberapapun menariknya destinasi Provinsi DIY menurut wisatawan domestik, hal ini tidak akan mampu merubah lama tinggal mereka.

Hal ini mengindikasikan bahwa wisatawan domestik yang berwisata ke Provinsi DIY telah merencanakan secara pasti lama kunjungnnya dengan tidak mempertimbangkan faktor daya tarik destinasi. Jika diasumsikan bahwa destinasi wisata yang menarik akan membuat wisatawan tinggal lebih lama, maka bagi wisatawan domestik hal itu tidak demikian adanya. Masalah ini sesungguhnya sesuatu yang dapat diterima karena berbagai hal. Diantaranya adalah faktor luasan wilayah Provinsi DIY yang tergolong sempit sehingga sangat mungkin bagi wisatawan untuk mengunjungi berbagai obyek wisata utama yang ada hanya dalam kurun waktu tidak lebih dari 2 hari.

Selain itu, faktor lain yang memungkinkan hal ini terjadi adalah karena mereka telah merencanakan durasi kunjungan hanya 1 atau 2 hari saja. Hal lain yang mungkin menjadi penyebab adalah keterbatasan waktu luang yang dimilikinya. Sebagaimana fenomena yang terjadi akhir-akhir ini adalah bahwa ketika terdapat hari libur $2 \mathrm{~s} / \mathrm{d} 3$ hari di akhir minggu banyak sekali wisatawan domestik yang datang ke Provinsi DIY untuk berwisata.

\section{Wisatawan Asing}

Hasil penelitian menunjukkan bahwa terdapat pengaruh secara positif dan signifikan antara daya tarik destinasi terhadap lama tinggal wisatawan (LOS). Hal ini menginfor- masikan bahwa persepsi wisatawan asing tentang daya tarik destinasi ternyata mampu membuat mereka tinggal lebih lama di Provinsi DIY.

Sebagaimana terungkap dalam data penelitian bahwa mayoritas wisatawan adalah free individual traveler yang tidak menggunakan jasa travel agent dalam melakukan kegiatan wisatanya. Hal ini memberikan peluang bagi mereka untuk mengatur secara penuh aktivitas wisatanya di destinasi yang mereka inginkan. Dengan demikian maka ada kemungkinan bagi mereka untuk merubah rencana lama tinggalnya di destinasi tertentu seperti di Provinsi DIY ketika mereka memiliki anggapan bahwa destinasi ini layak untuk ditinggali lebih lama lagi karena menurut mereka cukup menarik.

\section{PENGARUH PERSEPSI TENTANG KUALITAS PELAYANAN WISATA TERHADAP LAMA TINGGAL WISATAWAN}

\section{Wisatawan Domestik}

Hasil analisis statistik menunjukan bahwa tidak terdapat pengaruh yang signifikan antara persepsi wisatawan tentang kualitas pelayanan wisata terhadap lama tinggal wisatawan (LOS). Oleh karena itu dapat disimpulkan bahwa walaupun persepsi wisatawan domestik tentang kualitas pelayanan wisata di Provinsi DIY memiliki pengaruh yang positif, namun hal itu tidak cukup kuat untuk menambah lama tinggal mereka. Dengan kata lain persepsi yang baik terhadap kualitas pelayanan wisata yang mereka peroleh selama berwisata di Provinsi DIY tidak dapat menjadikan mereka merubah durasi kunjungan wisatanya.

Kondisi ini sangat dimungkinkan karena memang wisatawan domestik terikat dengan jadwal atau rencana kunjungan yang telah dibuat sebelumnya. Jadi walaupun wisatawan domestik merasa sangat puas terhadap kualitas pelayanan wisata yang diterimanya, namun lama tinggal mereka tetap sesuai rencana awalnya. Masalah ini kemungkinan besar terkait dengan pola kunjungan yang 
Nur Budhi Puji Wibowo, Pengaruh Motivasi Wisata, Persepsi tentang Daya Tarik dan Kualitas Pelayanan terhadap Lama...

lebih terkonsentrasi pada akhir minggu (weekend) atau pada saat liburan panjang (long weekend) yang biasanya juga berada di akhir dan awal minggu. Terlebih lagi, lama masa libur tersebut biasanya juga hanya berkisar 3 hari saja. Hal-hal semacam inilah yang membuat lama tinggal wisatawan domestik relatif tidak begitu lama, hanya pada kisaran 2 s/d 3 hari.

Kemungkinan lain yang patut diduga mendukung hasil temuan ini adalah karena wisatawan domestik bersifat lebih permisif terhadap kekurangan kualitas pelayanan yang mereka terima selama berwisata, apalagi jika mereka berada pada situasi yang sulit untuk membuat pilihan alternatif terhadap jenis layanan yang diinginkan. Hal ini seringkali terjadi pada saat-saat puncak kunjungan, dimana terjadi penumpukan jumlah wisatawan dan kadang-kadang hampir melampaui daya dukungnya (carrying capacity). Hal inilah yang membuat mereka terkadang kurang memperhatikan kualitas pelayanan wisata yang seharusnya mereka peroleh dari para pelaku wisata di Provinsi DIY.

\section{Wisatawan Asing}

Hasil analisis menunjukkan bahwa terdapat pengaruh yang signifikan antara persepsi wisatawan tentang kualitas pelayanan wisata terhadap lama tinggal wisatawan (LOS). Berdasarkan hasil temuan diatas, terlihat bahwa wisatawan asing cukup concern terhadap kualitas pelayanan wisata yang mereka peroleh selama berwisata di Provinsi DIY. Artinya adalah bahwa jika wisatawan asing merasa mendapatkan pelayanan yang baik dan mereka merasa puas, maka ada kemungkinan mereka akan menambah lama tinggalnya. Lebih lanjut, kualitas pelayanan ternyata mampu membuat sekitar $5,9 \%$ wisatawan asing mau menambah lama tinggalnya di Provinsi DIY.

\section{PENGARUH MOTIVASI WISATA, PERSEPSI TENTANG DAYA TARIK DESTINASI DAN KUALITAS PELAYANAN WISATA TERHADAP LAMA TINGGAL WISATAWAN}

\section{Wisatawan Domestik}

Analisis data penelitian menunjukan bahwa terdapat pengaruh secara positif dan signifikan antara motivasi wisata, persepsi wisatawan tentang daya tarik destinasi serta kualitas pelayanan wisata secara bersama-sama terhadap lama tinggal wisatawan (LOS). Melihat hasil analisis data penelitian diatas, dapat diperoleh fakta bahwa ternyata wisatawan domestik memiliki kecenderungan dapat menambah lama tinggalnya di Provinsi DIY jika mereka datang dengan didorong oleh motivasi wisata yang kuat, memiliki persepsi yang baik tentang daya tarik destinasi yang ada, serta mendapatkan pelayanan wisata yang berkualitas, sesuai dengan yang mereka harapkan. Keputusan ini dapat mereka ambil terutama bagi kelompok wisatawan domestik yang berwisata secara mandiri, tanpa menggunakan jasa travel agent.

Dilihat dari karakteristik demografisnya, sangat memungkinkan bagi wisatawan untuk tinggal lebih lama di Provinsi DIY karena mereka mayoritas berasal dari daerah-daerah di Pulau Jawa yang relatif mudah aksesibilitasnya. Harga berbagai fasilitas akomodasi, makanan dan minuman, serta beberapa produk barang dan jasa lainnya yang menjadi kebutuhan mereka selama berada di Provinsi DIY yang relatif murah dan terjangkau juga merupakan salah satu faktor pendukung.

Selanjutnya, jika diperhatikan dari sisi karakteristik psikografis yang lainnya, maka wisatawan domestik yang datang dengan tujuan untuk mengikuti seminar, pelatihan, dan pameran atau event-event khusus, ternyata lebih potensial jika dilihat dari sisi lama tinggalnya. Untukitu strategi pemasaran yang harus dilakukan adalah dengan mempromosikan Provinsi DIY sebagai destinasi wisata MICE yang terbukti lebih efektif untuk meningkatkan lama tinggal wisatawan tersebut. 


\section{Wisatawan Asing}

Berdasarkah analisis statistik diketahui bahwa terdapat pengaruh yang positif dan signifikan antara motivasi wisata, persepsi wisatawan tentang daya tarik destinasi serta kualitas pelayanan wisata secara bersamasama terhadap lama tinggal wisatawan (LOS). Hasil analisis tersebut menginformasikan kepada kita bahwa secara bersamaan, ketiga hal tersebut mampu membuat wisatawan untuk tinggal lebih lama. Fakta ini didukung oleh adanya data bahwa mayoritas wisatawan asing lebih mandiri dan bebas mengatur aktivitas wisatanya. Mereka tidak terikat dengan travel agent tertentu, memiliki pendapatan yang relatif tinggi dan berusia relatif muda.

Dari hasil analisis regresi ganda yang dilakukan baik terhadap wisatawan domestik maupun asing, terlihat bahwa nilai-nilai koefisien variabel motivasi wisata, persepsi tentang daya tarik destinasi, dan persepsi tentang kualitas pelayanan wisata adalah kecil. Hal ini mengindikasikan bahwa secara bersama-sama, ketiga variabel bebas tersebut memiliki kekuatan penentu yang kecil terhadap lama tinggal wisatawan di DIY. Hal ini terlihat dari koefisien penentu (koefisien determinasi) untuk wisatawan domestik sebesar $26,1 \%$ dan $16,1 \%$ untuk wisatawan asing.

Berdasarkan hasil temuan ini diperoleh fakta bahwa variabel motivasi wisata wisatawan dan persepsinya terhadap daya tarik destinasi wisata serta kualitas pelayanannya, ternyata bukan merupakan faktor penentu yang cukup dominan untuk menentukan lama tinggal mereka selama berwisata di Provinsi DIY. Hal ini berlaku untuk kedua jenis wisatawan (wisatawan domestik dan asing). Namun demikian, ada perbedaan yang cukup signifikan antara besarnya koefisien determinasi pada jenis wisatawan domestik dan asing yaitu sebesar $10 \%$, dimana koefisien determinasi wisatawan domestik lebih besar.

Lebih lanjut berdasarkan besarnya koefisien determinasi tersebut, dapat diduga kuat bahwa hal itu terjadi karena adanya beberapa perbedaan berdasarkan karakteristik secara geografis, demografis, maupun psikografis antara wisatawan domestik dan wisatawan asing. Sebagai contoh misalnya dari segi geografis, wisatawan domestik lebih dekat jika dibandingkan dengan wisatawan asing sehingga dapat berpengaruh terhadap motivasi wisatanya, maupun persepsinya terhadap daya tarik destinasi karena perbedaan kualitas dan kuantitas informasi yang diperolehnya tentang destinasi Provinsi DIY.

Penyebab lain yang dimungkinkan adalah adanya perbedaan pola kunjungan wisata antara wisatawan domestik dan wisatawan asing. Wisatawan domestik cenderung memilih Provinsi DIY sebagai destinasi tunggal. Artinya dalam sekali perjalanan wisata yang dilakukan hanya Provinsi DIY yang menjadi tujuan. Sedangkan wisatawan asing memilih destinasi Provinsi DIY sebagai salah satu destinasi dari kunjungan wisatanya di Indonesia.

Kondisi tersebut membuat wisatawan asing tidak merencanakan untuk tinggal lebih lama dibandingkan dengan destinasi utamanya, misalnya Bali. Untuk itu perlu usaha yang keras bagi para stakeholder untuk dapat menjadikan Provinsi DIY menjadi destinasi tujuan utama (main destination) bagi wisatawan asing. Hal ini perlu dilakukan agar peningkatan jumlah kunjungan wisatawan dan lama tinggalnya dapat diwujudkan.

\section{KESIMPULAN}

(1). Terdapat pengaruh positif dan signifikan antara motivasi wisata terhadap lama tinggal wisatawan (LOS) di Provinsi DIY untuk wisatawan domestik. Namun bagi wisatawan asing, motivasi wisata ternyata tidak berpengaruh secara signifikan terhadap lama tinggal di Provinsi DIY; (2). Tidak terdapat pengaruh yang signifikan antara persepsi wisatawan tentang daya tarik destinasi terhadap lama tinggalnya di Provinsi DIY untuk wisatawan domestik. Disisi lain, untuk wisatawan asing, ternyata persepsi tentang daya tarik destinasi memiliki 
pengaruh yang positif dan signifikan terhadap lama tinggalnya; (3). Tidak terdapat pengaruh yang signifikan antara persepsi wisatawan tentang kualitas pelayanan wisata terhadap lama tinggalnya di Provinsi DIY untuk wisatawan domestik. Bagi wisatawan asing, persepsi tentang kualitas pelayanan wisata ternyata berpengaruh secara positif dan signifikan terhadap lama tinggalnya; (4). Terdapat pengaruh yang positif dan signifikan antara motivasi wisata, persepsi wisatawan tentang daya tarik destinasi serta kualitas pelayanan wisata secara bersama-sama terhadap lama tinggal wisatawan (domestik dan asing) di Provinsi DIY.

\section{SARAN}

Memperhatikan hasil penelitian, selanjutnya disampaikan beberapa saran: (1). Sektor Pemerintah Daerah Dinas Pariwisata. a). Diperlukan peran pemerintah secara terpadu untuk menciptakan atmosfer yang kondusif dalam penyelenggaraan kegiatan kepariwisataan. Selain itu juga perlu dirancang kebijakan strategis bidang kepariwisataan, serta peningkatan kegiatan promosi dan pemasaran untuk menjangkau pasar potensial baru; b). Perlu ditingkatkan promosi Provinsi DIY sebagai destinasi wisata MICE, mengingat potensi yang cukup besar.

(2). Sektor Obyek dan Daya Tarik Wisata, a). Diperlukan peningkatan kualitas dan profesionalisme dalam penyelenggaran destinasi wisata di Provinsi DIY untuk menjamin kepuasan wisatawan. Hal ini penting untuk membangun citra positif sebagai daerah tujuan wisata utama di Indonesia baik di mata wisatawan domestik maupun wisatawan asing; b). Diperlukan kreativitas pengelola obyek wisata dalam mengemas produk yang ditawarkan agar lebih inovatif guna mengantisipasi kejenuhan pasar, juga penciptaan atraksi di malam hari yang lebih bayak lagi untuk meningkatkan lama tinggal wisatawan; c). Perlu melakukan usaha promosi dan pemasaran secara langsung dan mandiri (tidak tergantung pemerintah) terutama dengan menggunakan media internet untuk menjangkau pasar calon wisatawan asing yang telah terbukti cukup efektif sebagai referensi wisatawan asing.

(3). Sektor Akomodasi, a). Hotel non bintang sebagai salah satu pilihan sarana akomodasi kian mendapat respon yang baik dari pasar, baik wisatawan domestik maupun asing. Untuk itu perlu adanya peningkatan standart kualitas pelayanan di setiap lini; $b$ ). Hotel berbintang perlu terus meningkatkan kualitas pelayanannya serta tetap memperhatikan tingkat harga yang kompetitif. Wisatawan asing memilih hotel berbintang sebagai pilihan utama akomodasinya. Untuk itu kepastian pelayanan dan kualitas harus menjadi perhatian utama.

(4). Sektor Biro Perjalanan Wisata, a). Sudah saatnya biro perjalanan wisata merancang paket wisata yang lebih spesifik, menarik, dan responsive terhadap selera pasar yang bersifat lebih personal namun tetap kompetitif dari segi harga; b). Perlu di tingkatkan usaha menjual paket wisata alternatif diluar paket wisata konvensional saat ini.

(5). Sektor Penerbangan dan Transportasi, a). Sebagian besar wisatawan masuk ke Indonesia melalui Jakarta dan Bali. Salah satu akibatnya adalah mereka menjadikan Provinsi DIY sebagai destinasi tambahan/alternatif saja sehingga lama tinggalnya rendah. Untuk itu jika dimungkinkan agar dibuka akses penerbangan langsung dari Provinsi DIY ke berbagai negara sumber wisatawan potensial atau negara penghubung, Singapura, Thailand, dan Australia untuk mengakselerasi jumlah wisatawan asing yang datang; $b$ ). Dibidang transportasi lokal, perlu ditambah moda angkutan umum lokal yang memadai (Trans Jogja dan sejenisnya) yang dapat menghubungkan lebih banyak lagi titik-titik obyek wisata di DIY sehingga mempermudah mobilitas wisatawan dari satu obyek ke obyek yang lainnya. Volume kendaraan yang kian tidak sebanding dengan kapasitas jalan juga perlu segera dicarikan solusinya untuk menghindari kemacetan yang semakin sering terjadi belakangan ini. 
DAFTAR PUSTAKA

Badan Pariwisata Provinsi DIY. 2007. Statistik Kepariwisataan DIY tahun 2007. Yogyakarta: Baparda.

Badan Pariwisata Provinsi DIY. 2007. Renstra Baparda DIY. Yogyakarta: Baparda.
Departemen Kebudayaan dan Pariwisata RI. 2008. Statistic Report on Visitor Arrivals to Indonesia. www.budpar.go.id. Diakses tanggal 10 Desember 2008.

United Nations World Tourism Organisation. 2005. Tourism Highlight 2005. Madrid: UNWTO. www.unwto.org. diakses tanggal 10 Desember 2008. 